This item was submitted to Loughborough's Research Repository by the author.

Items in Figshare are protected by copyright, with all rights reserved, unless otherwise indicated.

\title{
Fool's gold? A critical assessment of sources of data on heritage crime
}

\section{PLEASE CITE THE PUBLISHED VERSION}

https://doi.org/10.1108/DPM-07-2018-0232

\section{PUBLISHER}

(c) Emerald

\section{VERSION}

AM (Accepted Manuscript)

\section{PUBLISHER STATEMENT}

This work is made available according to the conditions of the Creative Commons Attribution-NonCommercialNoDerivatives 4.0 International (CC BY-NC-ND 4.0) licence. Full details of this licence are available at: https://creativecommons.org/licenses/by-nc-nd/4.0/

\section{LICENCE}

CC BY-NC-ND 4.0

\section{REPOSITORY RECORD}

Nicholas, Louise, Suzie Thomas, and Adam Daubney. 2018. "Fool's Gold? A Critical Assessment of Sources of Data on Heritage Crime". figshare. https://hdl.handle.net/2134/35806. 


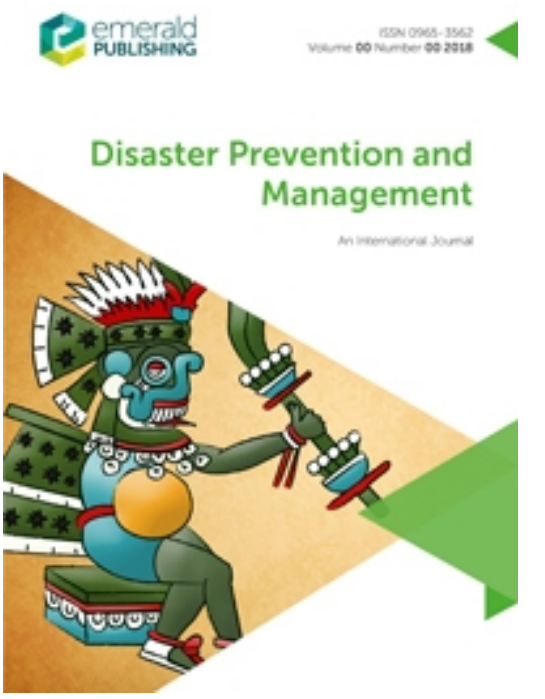

\section{Fool's Gold? A critical assessment of sources of data on heritage crime}

\begin{tabular}{|r|l|}
\hline Journal: & Disaster Prevention and Management \\
\hline Manuscript ID & DPM-07-2018-0232.R1 \\
\hline Manuscript Type: & Research Paper \\
\hline Keyword: & heritage crime, data, dark figure, theft, criminal damage \\
\hline
\end{tabular}

\section{SCHOLARONE $^{\text {IM }}$ Manuscripts}


Fool's Gold? A critical assessment of sources of data on heritage crime

\title{
Fool's Gold? A critical assessment of sources of data on heritage crime
}

\begin{abstract}
Purpose To explore critically various sources of data available on heritage crime, and consider how these may be utilised and improved.

Design/methodology/approach Primarily a scoping review of the current heritage crime data climate, embedding examples from a range of existing and potential information sources. It highlights opportunities to improve data resources.

Findings A lack of consistency in reporting and recording practices means there is little meaningful evidence about heritage crime trends and patterns. This needs to change in order to develop and evaluate appropriate strategies to reduce the problem of heritage crime nationally and internationally.

Research limitations/implications It is hoped that by urging improvement of data resources in the heritage crime sector will inspire a greater number of researchers to analyse and address key problems within heritage crime.

Practical implications This paper encourages the development of new and improved data collection methods to foster effective assessment of existing heritage crime reduction schemes and better support victims of heritage crime.

Social implications Increasing availability and accessibility of high quality data on heritage crime would allow for developing better protections and resource allocation for vulnerable heritage.

Originality/value This paper has drawn together, for the first time, evidence of the existing state of affairs of data availability within heritage crime. It is a position paper which encourages the development of improved recording and reporting practices both formally and informally across heritage and criminal justice sectors in order to support further research and understanding of the heritage crime problem.
\end{abstract}

Keywords

Heritage crime; data; dark figure; theft; criminal damage 
Fool's Gold? A critical assessment of sources of data on heritage crime

\section{Introduction}

Heritage crime is a relatively recent way of looking at crimes that affect the historic environment and broader cultural heritage. It is an interdisciplinary approach to an ancient problem - that of deliberate damage to and destruction of the historic environment. Definitions are continually being debated and discussed with key questions around who defines the ownership of heritage (Hodder 2010), the role of the State in its protection or destruction (Hutchings and La Salle 2017), what damage is in itself worthy of protection (cf. Forster, Vettese-Forster and Borland, 2012 on assessing the cultural worth of ancient and contemporary graffiti) being just some areas of debate. Within this paper, the term heritage crime is used in a pragmatic sense: 'any activity that is prohibited by law that causes loss of, damage to, or other harm to places, monuments or objects considered to be heritage' (Thomas and Grove (2014: 5). This is not to dismiss the importance of those other debates, but is a recognition that law enforcement and heritage bodies cannot reasonably be expected to work regularly outside such frameworks.

There are many examples of heritage crime from around the world, including: the destruction of assets at sites such as Nimrud in Iraq through terrorist activity (Danti, 2015); damaging graffiti at Clifford's Tower in England (Shelbourn, 2014); arson at Fantoft Stave Church in Norway (Jerome, 2008); architectural theft and illegal export of Finnish design (Thomas, 2014); looting from the Dodington shipwreck off the coast of South Africa (Vollgraaff, 2014); art stolen from the Isabella Stewart Gardner Museum, for which there is still a reward of $\$ 10$ million (Gardner Museum, 2018), as well as the widespread erasure of indigenous traditions, language, and cultures as a result of deforestation (Mitten, 2007). This is before even considering the extensive literature on the global trafficking of cultural objects (e.g. Brodie et al. 2006). It is inevitable that many of these heritage assets are in rural or remote areas, which exacerbates the difficulties associated with identification of criminal activity.

Whilst many of these issues have come to public attention over the years, there are many more that remain undiscovered, or known only to a small number of individuals. Researchers have often turned their gaze to the higher value or higher profile examples of heritage crime, particularly that related to trade in 
antiquities, overlooking the greater volume of low-value cultural objects also in circulation on the market (Thomas 2016: 144-145). It is difficult to know the true nature and extent of heritage crime, especially rural heritage crime, as a result. This is important because without a baseline understanding of heritage crime, it is not possible to measure whether the problem is increasing or decreasing, nor can hotspots of illicit activity within which to direct crime prevention resources be identified. Market reduction approaches (e.g. Mackenzie 2011) cannot be developed without an appreciation of the nature of the market, nor can Roach and Pease's (2016) concept of self-selection policing (that people who commit big crimes also commit little crimes - and the former can be identified by understanding more about the latter) be relied upon if there is no record of lower profile crimes taking place.

The purpose of this paper, therefore, is to explore critically the various sources of data available on heritage crime, and consider how these may be utilised and improved, as well as what alternatives may be available in the future. The area context is predominantly that of England and Wales, however the issues raised are equally applicable on an international stage.

\section{Finding the data: the dark figure of unreported crime}

The dark figure of crime refers to the large amount of crime that 'evades the attention of monitoring systems devised to measure its volume and distribution' (Skogan, 1977: 41). It applies here to heritage crime because much of heritage crime is unrecognised and unreported. This is a particular issue because whilst the remainder of the paper discusses issues around data collection and access, many of the mechanisms deliberated are reliant on the public recognising an incident as a crime and reporting it as such. This then needs to be recorded appropriately by the police.

When considering data about crime, the first source utilised is often the recorded crime available on police systems. In England and Wales there are three common ways of accessing police data. The first of these is open source crime data which is made freely available on the specialist website police.uk. This provides access to a sterilised dataset - covering aggregated crime type, approximate 
location, and outcome - with the aim of improving accountability of the police service (Shadbolt et al. 2012: 16). Privacy legislation, such as the Data Protection Act 1998, in part limits this data, making it deliberately obfuscated for public consumption which severely limits its utility (Quinn, Cooke and Monaghan, 2017). Of particular interest here, is that not only is there is no category for heritage crime - about which more later - but nor is there a way in which to overlay heritage assets with the available crime data as addresses are obscured. In all, there is little utility of this dataset for (heritage crime) researchers and it does not allow for 'sophisticated research outside of police intelligence hubs' (Quinn, Cooke and Monaghan 2017: 13).

In England and Wales, there are two alternative ways of accessing relevant police data for heritage crime researchers: Freedom of Information Act (2000) requests, and negotiating direct access to force data through individual forces. These have both shared and independent problems. The Freedom of Information Act 2000 allows for more nuanced data to be requested than is available on police.uk, and each request is considered by forces on an individual basis. Requests should be responded to within 20 working days, and can provide access to more specific pieces of information such as crime type and time of day. However, there are limitations to the Act, and each request may be interpreted differently by individual forces (see Daubney and Grove, forthcoming, for an example of the limited information made available in response to an FOI request on the heritage crime of illicit metal detecting). In addition, the searches required to identify relevant data can be time consuming for the forces involved, and for that reason there is a cost and time limitation on FOI requests (Kingston, Elliott and Thomas 2018). This is applied inconsistently across Forces, and is often mirrored by differences in the way that data is accessed and recorded. There are problems that are common between FOI requests and direct access to police data, as they effectively draw on the same resource in two different ways.

There is usually no 'flag' on the police system to indicate heritage crime (with one known exception, see below). Many other crimes, such as hatemotivated crimes, can be flagged as such by police officers using a checkbox when filling out the crime information on the database (O'Neill 2017). This enables the data to be easily retrieved, monitored, and compared across forces. Without this facility, searches for crime types that do not fall into one of the Home Office's 
specific offence classifications (see https://www.gov.uk/government/publications/counting-rules-for-recorded-crime for an up to date list of crimes recorded on the police database) are largely reliant on free-text searches and/or a manual examination of details of crime incidents. Free text fields are often poorly and inconsistently utilised, which means that the level of detail may vary, spelling errors and abbreviations are common, and not all sections are filled out - in short, it becomes difficult to use (Chau, $\mathrm{Xu}$ and Chen 2002). Even where researchers or analysts can identify offences, there are wellknown issues reconciling addresses on police databases with real-world locations (see for example Ratcliffe and MuCullagh 1998). This is particularly salient for heritage assets as they may be known by a different name as a heritage asset than as a street address (for example The Old Post Office may also be known as 3 High Street, or may have been separated into multiple residences). Leicestershire Police are one force that have been proactive in improvements to heritage recording in the crime database, and have provided a tick box to highlight heritage-relevant offences. They are not currently able to assess to what extent officers are using this - and it may be that officers are attending offences and not realising that they are at a heritage asset. One solution under development by Historic England and researchers at Canterbury Christ Church University is a 'proximity app' to inform officers of the protected heritage status of sites they attend.

In addition to problems of recording, there are the difficulties in gaining direct access to police data: this is not possible for all researchers, particularly those without a recognised institutional affiliation, and often relies on direct personal connections which are difficult to duplicate across multiple police force areas. There are also often limits on what may be used due to ethical and privacy considerations, particularly when making use of open source data and FOI requests. A second limitation is the aforementioned flaws in the underpinning data, with existing data not immediately useful for heritage crime researchers.

\section{Under-reporting of heritage crimes}

Some developments which may improve the situation for knowledge and understanding are in progress. Most police forces in England and Wales are now making use of heritage crime officers, who take the lead on local heritage crime issues. This arguably improves awareness both within and outside of the force. 
However, these officers take on the duties on top of other roles, and have little resource to back up their work. As a result, the focus is inevitably on a relatively narrow range of issues, most notably lead theft from church roofs which is a particularly high-profile crime at present. This means that many forms of heritage crime are still relatively under-recorded on the system, even where crimes are identified and reported.

The problem of under-reporting and recording is well recognised in other crime areas. Researchers often attempt to circumvent this by using crime survey data to supplement or as an alternative to police recorded statistics. This goes some way toward addressing the aforementioned dark figure of crime because surveys approach individuals (or businesses) directly in order to ascertain their experiences of victimisation. The main victim survey in England is the Crime Survey for England and Wales (CSEW), which is run by the Office for National Statistics (ONS). Unlike police recorded data in England, the CSEW has the status of 'National Statistics' (ONS 2017) which reflects the high quality and reliability of the dataset. The CSEW (formally known as the British Crime Survey) has been running since 1981 (Kantar 2015) and is one of the largest social research surveys conducted in England and Wales (Home Office 2012). Internationally, similar surveys exist such as the National Crime Victimization Survey in the USA, and the International Crime Victims Survey which is a multi-lingual Europe-wide effort. These are invaluable sources of data for crime researchers, but they do not include any questions about heritage. It is feasible that in sections on property crime there could, in the future, be an additional question regarding heritage status. However, this may make it easier to identify individual addresses; at present the data cannot be disaggregated to this extent. Additionally, the survey is expensive and timeconsuming to run, and new questions are infrequently added to the survey (recent examples being related to online crime). It therefore seems unlikely that a question on heritage will be added in the foreseeable future, particularly as this would relate to a relatively small subset of the sample.

This lack of focus on heritage-specific topics in existing crime surveys leads to considering heritage-crime as a survey topic in its own right. There have been two large-scale national research surveys published in this that would fit this category. In 2009, Oxford Archaeology published the 'Nighthawking Survey'. The report itself, while bringing the issue of nighthawking (more usefully known as 
Fool's Gold? A critical assessment of sources of data on heritage crime

illicit metal detecting) back into public discourse at a time when this had abated slightly, can also be criticised, for example due to the relatively low numbers of metal detectorists consulted in the data collection phase (Thomas 2013). In 2011/12 two of the present authors collaborated on the Heritage Crime Survey with scholars from Newcastle University (Coombes et al 2012) funded by what was then English Heritage (now renamed Historic England). The project brief was to explore the concept of heritage crime, as defined then by English Heritage as 'any offence which harms the value of England's heritage assets and their settings to this and future generations' (Coombes et al 2012: 7). The study assessed the extent to which heritage crime could be detected from the available data at that time collected via surveys, police reports, records kept by special interest groups and other sources. The key finding from that survey was that there were an estimated 75,000 crimes affecting designated historic buildings and sites in 2011 (English Heritage, 2012) - a substantial number. This survey has not been duplicated since, and there is no way of telling whether 2011 was a representative year, nor what trends have been seen in heritage crime, or indeed in the way in which such crimes are recorded, since the survey.

In other countries and regions, there have also been attempts to collect data on heritage crimes. One notable example is the report Cultural Heritage Crime: The Nordic Dimension (Korsell et al. 2006), which drew together available data for Denmark, Finland, Norway and Sweden. Other internationally-focused sources of data on heritage crimes include the International Council of Museums' Red Lists series (http://icom.museum/programmes/fighting-illicit-traffic/red-list/), as well as lists of known stolen cultural object kept by such as Interpol. These efforts generally focus on one particular kind of heritage crime - looting and trafficking of cultural objects - as their focus tends not to be on the broader spectrum of offenses that may be considered to be heritage crime.

A specific problem with surveying crimes and incidents at heritage assets is that they often have no on-site owner, tenant, or manager. It can be difficult to identify the correct person to talk to about incidents - and even where a person may be identified, it does not necessarily follow that they are monitoring the asset closely. For example, signs of illicit metal detecting on a scheduled monument may be disturbed ground and/or tyre tracks, which could be dismissed or ignored without specific cause to check. Other times the natural action of wildlife such as 
rabbits or moles may be misinterpreted as signs of illicit digging. Many rural assets are isolated which leaves them not only at risk of crime going unnoticed, but also of longer term damage.

Historic England tackles the issue of the deterioration of heritage assets with the annual publication of the Heritage at Risk (HAR) register. The HAR register focuses on deterioration of and damage to assets that are included in the National Heritage List for England (NHLE), such as Grade 2, 2*, and Grade 1 listed buildings, scheduled monuments, registered battlefields, registered parks and gardens, protected wreck sites, and conservation areas. While the NHLE includes around 400,000 assets, this represents just a small portion of the total number of historic sites and monuments across England and Wales which are afforded little or no protection. Assets included in the HAR register are rated according to a number of categories, such as vulnerability, condition, ownership, and priority. 'If a site has suffered from heritage crime it is noted in the summary' (Historic England 2017) but this is not highlighted as a category in its own right, and nor is the data easily searchable. Unlike the National Heritage List for England, which identifies all protected heritage assets in England and provides data for download and manipulation, the HAR register is published regionally in pdf format. Although a search function exists via the Historic England website, this is not sufficiently granular to permit a search by victimisation. However, the HAR register provides a potential future route for data collection on heritage crime at the most vulnerable sites.

Data on heritage crime principally concerning illicit metal detecting and/or potential breaches of the Treasure Act (1996) in England and Wales are collated in an informal way by the Portable Antiquities Scheme (PAS). The PAS was established in 1997 as mechanism through which archaeological artefacts discovered by the public in England and Wales could be recorded. The scheme is formed by a network of Finds Liaison Officers (FLOs) spread out the regions, who liaise directly with finders (mainly hobbyist metal detectorists). All finds recorded by the scheme are published onto their searchable online database ${ }^{1}$, though spatial and personal data are restricted to bona-fide researchers. While the scheme was established primarily as a way to encourage the recording of finds that do not fall

1 www.finds.org.uk/database 
under the Treasure Act (1996), the close liaison that FLOs have with the public has meant that they are often the recipients of information on illicit metal detecting and/or the illicit sale of antiquities. As a consequence, FLOs frequently liaise with law enforcement authorities. Information on the extent of this liaison has only been recorded systematically since 2015 and only in a broad way: the focus of these surveys are not to capture fine detail on specific incidents, but rather to establish broader trends in the reporting of illicit metal detecting, and also the amount of resource that is expended by the scheme in working with law enforcement authorities each year (Daubney 2017; Daubney and Grove forthcoming). Accordingly, PAS survey data includes both those incidents that were reported to the Police and which were acted upon, and also those incidents that were reported to Police and which resulted in no further action. Unfortunately the level of detail captured by the PAS surveys do not allow it to be used to differentiate between the two.

At present, the Crown Prosecution Service, which is responsible for criminal prosecutions in England and Wales, records convictions under relevant heritage legislation - for example the Treasure Act 1996 and the Dealing in Cultural Objects (Offences) Act 2003. In practice these laws are rarely used to prosecute an offender, as they are often prosecuted under more common laws such as the Theft Act 1968. This means that there are very few offences identifiable as heritage crime, even though there may in practice be many more relevant prosecutions. As one example, the first prosecution under the Dealing in Cultural Objects (Offences) Act 2003 since its enactment did not come until 2016 (Herman 2016).

Changes to Sentencing Council guidelines, which give guidance on the appropriate prison (or other) sentences for all offences in England and Wales, mean that heritage is an aggravating factor for certain offences (see for example Sentencing Council 2015). This means that where, for example, damage is done under theft offences, but to a recognised heritage asset, judges and magistrates have the ability to hand down a more severe sentence. This may mean that records of heritage-related offences become easier to access in the future, although again this may depend on the ways in which the records are kept; free-text fields are invariably harder to search than separate categories or flags for offences. 
Data may also be available from a variety of commercial organisations. Some examples of this are insurance companies, auction houses, and businesses that sell crime prevention products. This data is not always accessible to researchers as in many cases commercial companies are under no obligation to share their data with others.

The Art Loss Register is 'the world's largest private database of lost and stolen art, antiques and collectables' (Art Loss Register 2018). By registering details of such items, the database taps into the principles of the Market Reduction Approach (Sutton 1998) - namely that by making potential buyers aware of the stolen nature of items, demand is reduced. The potential for recovery is also improved. However, as a commercial company the Art Loss Register charges a fee per search, which minimises its utility for items with a lower monetary value. Indeed, the Art Loss Register only really concerns 'art' that has been stolen from an existing collection; for obvious reasons it does not include items that have been stolen 'straight out of the ground'.

Auction houses also retain records of items that have been sold via their services. This helps build a picture of provenance of cultural and heritage artefacts. This is generally considered to be commercially sensitive information, and auction houses would not wish to risk being associated with potentially criminal activity, and therefore are unlikely to share data with researchers. While it can be possible to analyse data such as provenance descriptions, pre-sale estimates and final sales results (Brodie 2014), auction houses generally protect the identity of vendors through client confidentiality. Furthermore, some auction houses occasionally host private, invitation-only sales, for which there are often no publicly available records.

Access might be negotiated to other commercial providers, particularly where a mutual benefit can be demonstrated. There are specialist insurers who maintain datasets for certain items - in the UK for example, Ecclesiastical Insurance provides cover for many listed churches, and so will have data on claims made for thefts. Buildings with a 'listed' (protected heritage) status usually require specific insurance to cover additional costs associated with repair of these assets, and there will almost certainly be claims data scattered across a number of such insurers. Insurance data may be skewed toward higher value claims, due to the 
excess payable on a claim and the risk of increased premiums in future years making lower-value claims ineffective for the victim and if risks 'are likely to remain high after all reasonable precautions have been taken, the insurance company will not underwrite the risk' (Pease 1979: 32) so data does not account for uninsured properties, which may be proportionately more likely to be damaged. Insurance data can still provide an important (albeit limited) insight to the nature and extent of damage to many occupied heritage assets. The challenge is to access this commercially sensitive data in a usable format. This is a problem also for data from developers of commercial crime prevention products, who may be keen to share data only when it supports their claims to effectiveness.

\section{Collecting Heritage Crime Data}

There are pockets of data collection happening within voluntary groups, albeit sometimes with limited accuracy, that aim to reduce risk of heritage crime in their local area. In England there are a number of such groups: Heritage Watch; Church Watch; Rural Watch, as well as volunteers within the police service. Significant contributions are also made by individuals or groups who attempt to 'self-police' their hobby; this is particularly seen among metal detectorists who frequently report individuals who operate outside of the law. These tend to be decentralised groups that encourage reporting to the police, but may also retain limited records, or more likely an informal institutional knowledge which would be very useful if it were able to be collated, but currently remains in the grasp of a relatively small number of individuals. Oftentimes, individuals who make efforts to gather such data are more than willing to share (cf. the data on illicit metal detecting gathered by Mark Harrison of Historic England and presented in Daubney and Grove forthcoming) - the problem lies with identifying and contacting the relevant individuals and groups, as well as being able to assess the validity of any data gathered in such a fashion. The types of crimes which come to the attention of individuals and groups are invariably going to be skewed due to the interests of those involved, as well as the awareness of potential informants of the relevant contact details.

Related to this, it has been argued that many heritage projects and programmes aimed at increasing public engagement are rooted in an aim to reduce 
crimes such as looting and vandalism through raising awareness (Ellick 2016). What is less well known, and likely not recorded in most cases (or even possible to record), is the extent to which heritage crimes do reduce as a result of greater community involvement.

The HAR register relies to an extent on risk assessments on specific sites. This is a tactic that can be used on a far more widespread scale by individuals, organisations, and projects. This can be helpful when trying to decide where to prioritise resources. However, if they were also to be shared on a heritage crime database, available to registered professionals and researchers, this would provide an invaluable resource as a knowledge base on the nature and extent of heritage crime. Some police forces, for example Leicestershire Police, have developed risk assessments to be shared with managers of select heritage assets, although these are yet to be rolled out widely and are of limited use until this happens. Due to budgetary and staff limitations, much work on risk assessment relies on 'buy-in' from owners, managers, and tenants of heritage assets. Where the primary use of an asset is not as heritage - for example a church is used predominantly for worship rather than as a heritage asset - it may be more difficult to encourage individuals to participate. There is also little formal evaluation of the effectiveness and helpfulness of these risk assessments. It is useful to develop risk assessments for different contexts to facilitate thinking about important issues that impact on assets, and where appropriate preventive measures may be taken. Two of the authors of the present piece have previously collaborated on such work (see Grove, Daubney and Booth 2018) and explored various aspects of archaeological sites which may be linked with greater risk: using the acronym HOPPER to draw together aspects of History, Openness, Protected status, Publicity, Evasion, and Repeat Victimisation.

It may also be worth considering the role of the media. As heritage crime becomes more known and of greater interest to readers and viewers, the coverage may in turn become more comprehensive - which may be tracked via online tools such as Google Alerts. Whilst coverage itself will inevitably be skewed to more newsworthy cases - that it, those crimes that occur on a larger scale or with a greater negative impact on the community - the more reporting individuals see in the papers, the more likely they are to come forward via formal reporting 
Fool's Gold? A critical assessment of sources of data on heritage crime

mechanisms with information and incidents, which in turn improves our knowledge and understanding. Specific campaigns may also help with this process, as has recently been seen with the social and mainstream media coverage of the \#MeToo movement in relation to a $24 \%$ rise in police recorded sexual offences in the year ending March 2018 (ONS 2018).

When considering the nature and extent of heritage crime, much can be learned from individuals who directly deal with the effects of heritage crime. To date there is remarkably little work using interview data (at the time of writing the authors are only aware of Poyser and Poyser 2017) Where used, interview data can provide a wealth of useful information related not just to the nature and extent of heritage crime, but also where there may be conflicts between user groups and officials. Poyser and Poyser (2017) approached this question with an exploration of the differing views of heritage crime between police practitioners and heritage professionals. These differing attitudes led to frustrations between the two groups.

Innovative thinking is required when it comes to improving our knowledge base on heritage crime. The realm of so-called 'big data' provides many opportunities to identify heritage assets that have been targeted by offenders (Constantinidis 2016). Online auction sites and their equivalent on the dark web can be examined for stolen items being resold (Paul 2018). Photography repositories can be scraped for evidence of damage to heritage assets (Grove and Lockley in preparation).

Crowdsourcing and citizen scientists are used to great effect in other scientific research, and has been especially popular within the galleries, libraries, archives and museums (known shorthand as GLAM) community (Ridge 2014). It has also been put to good use in the monitoring of wildlife such as birds (Sullivan et al. 2014), and by media agencies for collecting public knowledge of historical periods such as First and Second World Wars and the Finnish Civil War (Seitsonen 2017), to name a few examples.

The heritage community benefits from a large number of volunteers and members of various organisations - for example the National Trust had 2.31 million members in 2016-17 (National Trust 2017: 5), while English Heritage had 918000 members in 2016-17 (English Heritage 2017). This enthusiasm is not unique to England or the UK. Similar member organisations exist around the world 
Fool's Gold? A critical assessment of sources of data on heritage crime

with comparable enthusiasm from members, such as the National Trusts in Australia and Canada. Tapping into this network could provide an excellent source of data - imagine a phone app for easy reporting of damage and uploading of images, automatically geotagged for identification of location - and such a project could be international in scope. Historic England's 'Enrich the List' may provide a template for such a project. ${ }^{2}$ 'Enrich the List' is a dedicated online service where members of the public can share their knowledge and pictures of sites and monuments listed on the NHLE. Most of the information submitted by the public includes photos of sites, stories, or anecdotes, which collectively enhance understanding of the past and present condition of a particular listing. All 'extra' information submitted by the public is moderated by staff from Historic England and then published online after the official entry for that place. Logically, the underlying crowd-sourcing philosophy behind 'Enrich the List' could be applied to heritage crime.

Alas, at present such a project that focusses on heritage assets (listed or otherwise) in England and Wales does not exist, and so researchers remain in limbo - knowing there is a heritage crime problem, but unable to map the extent. There are further challenges concerning data coverage in all areas of the world, particularly relatively remote places with vulnerable heritage assets within the landscape.

Preserving detailed digital records of heritage assets can be seen as controversial, but on the other hand provides a baseline record to compare against, should a heritage crime take place. Additionally, while some have argued against the prevalence of digital heritage due to the loss of authenticity and materiality (e.g. Rekrut 2014), it has also been seen elsewhere that digitizing cultural heritage, for example using 3D imaging, can not only provide a record of a site's state of preservation at a particular time, but can also open up access to remote locations for communities that have a connection to the site but lack the means to access it regularly (e.g. Haukaas and Hodgetts 2016). However, without large scale policies - possibly making use of crowdsourcing and other voluntary collaborative methods - coverage is likely to be patchy or connected to specific (and usually finite)

\footnotetext{
${ }^{2}$ https://www.historicengland.org.uk/listing/enrich-the-list/
} 
projects.

\section{A call to action}

Rather than conclude with a summing up of the points and observations made in this paper, the discussion will be closed with a call to action with regard to the future of heritage crime data. Good quality data is important for a number of reasons:

An understanding of the patterns in heritage crime is essential to know where it clusters, and therefore where to target limited crime prevention resources

Changes over time need analysis so that micro and macro trends can be identified - and predictions made on future trends. This is also useful to see whether interventions being made are having an effect

Knowing the extent of heritage crime allows an argument for a commensurate apportioning of resource to tackling the problems

It allows for an understanding of the shape of victimisation are some groups disproportionately affected over others? This is apparent for example in the field of green criminology: namely environmental racism whereby policies disproportionately affect ethnic minorities (cf. Cole and Foster, 2001). Good data allows identification of whether heritage is disproportionately deteriorating in areas of poverty, for example. Support can then be offered to the worst affected in society.

It is useful to know if there are links with other types of crime the aforementioned concept of self-selection policing. Again, the greater an understanding we have of these issues, the more able to target resources accordingly - if focusing on heritage offences can help to prosecute people who are also responsible for e.g. terrorist activity, this is a good use of resources.

This leads the argument naturally to a further point to consider. When there is greater reporting of a crime to the relevant authorities, this does not necessarily mean there are more incidents. Rather than greater numbers of incidents, greater reporting may mean more awareness of legalities, a greater identification of 
relevant incidents, and better knowledge of how to report. It may mean a greater confidence in reporting - as police are seen to take incidents more seriously there may be a boost to people being willing to report future events. The publicity surrounding successful prosecutions, can also increase people's belief that something can be done which again is linked to an increased level of reporting (cf. ONS 2018). For example the 2018 prosecution of divers looting a World War I Navy shipwreck received coverage from across UK media (cf. BBC 2018, Boyd 2018). A larger number of reports may also mean that recording practices have improved. Finally, as laws and Home Office counting rules change, incidents may be recorded as a crime by police where previously they were 'no-crimed', thus making figures look artificially higher in comparison with previous years.

The following steps are therefore suggested, initially in the English context but with the intention of rolling out successful elements to other countries and contexts once initial difficulties are ameliorated. Of course, all of the suggested methods focus predominantly on tangible heritage, and could be seen to neglect the intangible nature of much heritage - stories, culture, song, language for example. This reflects the more difficult nature of measuring such issues - and is in no way intended as a commentary on the relative importance of tangible and intangible heritage.

- A regular victimisation survey is undertaken, to get a snapshot of changes and progress

- Heritage crime is flagged as part of routine data collection in the police

- These two items combined provide police recorded data, and crime statistics that are not affected by changes in recording practices, for comparison purposes.

- An analyst should be appointed in the first instance to assess the national picture and to provide predictions of where future problem areas may lie. In the longer term, it would be useful to see a team akin to the National Wildlife Crime Unit be developed alongside an academic partnership to facilitate proactive working and the introduction of predictive and protective measures.

- In 2018, an All Party Parliamentary Group was established to focus on 
Fool's Gold? A critical assessment of sources of data on heritage crime

heritage crime issues (in particular metal and stone theft). Improving the quality of data recording and access to existing information should be a priority for this group in order that they can effectively measure future successes.

- In addition, innovative techniques should continue to be developed to make the most of data mining techniques and crowdsourcing technologies

Victims of heritage crime should be broadly defined, and consulted and considered throughout to develop an understanding of how these issues affect them.

Discovering how victims and communities feel heritage crime problems should be handled can lead to techniques being developed to reduce the impact on the victim, and not just focus on the built heritage.

\section{References}

Art Loss Register (2018), About Us. http://www.artloss.com/about-us/ourcompany [Accessed 13 June 2018]

BBC (2018), Pair plundered HMS Hermes shipwreck in Dover Strait 22 June 2018. https://www.bbc.com/news/uk-england-kent-44536788 [Accessed 30 July 2018]

Boyd, C. (2018), Diver and boat owner who stripped thousands of pounds of metal from shipwrecks including WWI cruiser HMS Hermes in the English Channel are jailed for up to four years each. 23 June 2018. http://www.dailymail.co.uk/news/article-5875537/Divers-strippedthousands-pounds-metal-shipwrecks-jailed-four-years-each.html [Accessed 30 July 2018]

Brodie, N. (2014), Provenance and price: autoregulation of the antiquities market? European Journal on Criminal Policy and Research, 20(4), 427-444.

Brodie, N., Kersel, M. M., Luke, C., \& Walker Tubb, K. (2006), Archaeology, cultural heritage, and the antiquities trade. University Press of Florida. 
Fool's Gold? A critical assessment of sources of data on heritage crime

Chau, M., Xu, J. J., \& Chen, H. (2002, May), Extracting meaningful entities from police narrative reports. In Proceedings of the 2002 annual national conference on Digital government research (pp. 1-5), Digital Government Society of North America.

Cole, L.W. and Foster, S.R., (2001), From the ground up: Environmental racism and the rise of the environmental justice movement. NYU Press.

Constantinidis D. (2016), Crowdsourcing Culture: Challenges to Change. In Borowiecki, K., Forbes, N., and Fresa, A. (eds), Cultural Heritage in a Changing World. Springer, Cham, pp215-234.

Coombes, M., Bradley, D., Grove, L., Thomas, S. \& Young, C. (2012), The extent of crime and anti-social behaviour facing designated heritage assets. English Heritage

Danti, M. D. (2015), Ground-based observations of cultural heritage incidents in Syria and Iraq. Near Eastern Archaeology, 78(3), 132-141.

Daubney, A. (2017), Floating culture: the unrecorded antiquities of England and Wales. International Journal of Heritage Studies, 23(9), 785-799.

Daubney, A. and Grove, L. (forthcoming), Detecting heritage crime(s): what we know about illicit metal detecting in England and Wales

Ellick, C. J. (2016), A Cultural History of Archaeological Education. Advances in Archaeological Practice, 4(4), 425-444.

English Heritage (2017), English Heritage Annual Report 2016/17. Swindon: English Heritage. http://www.englishheritage.org.uk/content/AboutUs/3439010/EHT_Annual_Report_201617.pdf [Accessed 9 July 2018]

Forster, A. M., Vettese-Forster, S., \& Borland, J. (2012), Evaluating the cultural 
Fool's Gold? A critical assessment of sources of data on heritage crime significance of historic graffiti. Structural Survey, 30(1), 43-64.

Gardner Museum (2018), Gardner Museum Theft An Active And Ongoing Investigation. https://www.gardnermuseum.org/organization/theft [accessed 13 June 2018]

Grove, L., Daubney, A., \& Booth, A. (2018), Identifying sites at risk from illicit metal detecting: from CRAVED to HOPPER. International Journal of Heritage Studies, 1-15.

Haukaas, C., and L. M. Hodgetts (2016), The untapped potential of low-cost photogrammetry in community-based archaeology: a case study from Banks Island, Arctic Canada. Journal of Community Archaeology \& Heritage 3(1), 40-56. DOI: doi.org/10.1080/20518196.2015.1123884

Herman, A. (2016), Conviction at last under 2003 Act. Institute of Art and Law, 11 May. https://ial.uk.com/1448-2/ [Accessed 5 July 2018].

Hodder, I. (2010), Cultural heritage rights: From ownership and descent to justice and well-being. Anthropological Quarterly, 83(4), 861-882.

Home Office (2012), British Crime Survey: methodology. London: Home Office. https://www.gov.uk/government/statistics/british-crime-survey-methodology [Accessed 13 June 2018]

Hutchings, R. M., \& La Salle, M. (2017), Archaeology as State Heritage Crime. Archaeologies, 13(1), 66-87.

Jerome, P. (2008), An introduction to authenticity in preservation. APT Bulletin, 39(2/3), 3-7.

Kantar (2015), About the Survey. http://www.crimesurvey.co.uk/HomeReadMore.html [Accessed 13 June 2018] 
Fool's Gold? A critical assessment of sources of data on heritage crime

Korsell, L., G. Hedlund, S. Elwér, D. Vesterhav, \& A. Heber. (2006), Cultural Heritage Crime: The Nordic Dimension; Stockholm: The Swedish National Council for Crime Prevention.

Mackenzie, S. (2011), The Market as Criminal and Criminals in the Market:

Reducing Opportunities for Organised Crime in the International Antiquities Market in Manacorda, S., and Chappell, D. (eds), Crime in the Art and Antiquities World. Springer. 69-85.

Mitten, L. (2007), The human cost of deforestation. Peace Review, 9(4), 549-553, DOI: $10.1080 / 10402659708426107$

National Trust (2017), National Trust Annual Report 2016/17. Swindon: National Trust. https://www.nationaltrust.org.uk/documents/annual-report-201617.pdf [Accessed 9 July 2018]

O'Neill, A. (2017), Hate Crime, England and Wales, 2016/17. Statistical Bulletin 17/17. London: Home Office.

https://assets.publishing.service.gov.uk/government/uploads/system/uploads/ attachment_data/file/652136/hate-crime-1617-hosb1717.pdf

ONS (2017), Crime in England and Wales: year ending June 2017. https://www.ons.gov.uk/peoplepopulationandcommunity/crimeandjustice/bu

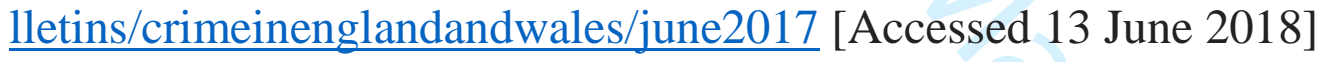

ONS (2018), Crime in England and Wales: year ending March 2018. https://www.ons.gov.uk/peoplepopulationandcommunity/crimeandjustice/bu

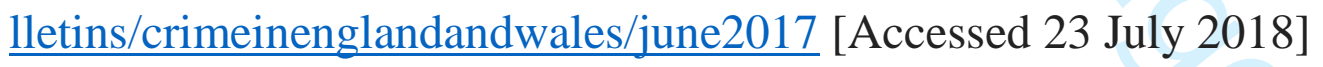

Paul, K. A. (2018), Ancient Artifacts vs. Digital Artifacts: New Tools for Unmasking the Sale of Illicit Antiquities on the Dark Web. Arts 7(2), 12. DOI: $10.3390 /$ arts7020012

Pease, K., (1979), Some futures in crime prevention. Home Office Research Bulletin, 7, pp.31-35. 
Fool's Gold? A critical assessment of sources of data on heritage crime

Poyser, B. and Poyser, S., (2017), Police practitioners and place managers' understandings and perceptions of heritage crime in Nottinghamshire. International Journal of Police Science \& Management, 19(4), pp.247-260.

Quinn, A., Cooke, L., \& Monaghan, M. (2017), An exploration of the progress of open crime data: how do ongoing limitations with the Police.uk website restrict a comprehensive understanding of recorded crime?. Policing and Society, 1-16.

Ratcliffe, J. H., \& McCullagh, M. J. (1998), Identifying repeat victimization with GIS. The British Journal of Criminology, 38(4), 651-662.

Rekrut, A. (2014), Matters of Substance: Materiality and Meaning in Historical records and their Digital Images. Archives and Manuscripts 42(3): 238-247.

Ridge, M. (2014), Crowdsourcing our Cultural Heritage: Introduction. In M. Ridge (ed.), Crowdsourcing our Cultural Heritage, London, New York: Routledge. 1-13.

Roach, J., \& Pease, K. (2016), Self-Selection Policing: Theory, Research and Practice. Springer.

Seitsonen, O. (2017), Crowdsourcing cultural heritage: public participation and conflict legacy in Finland. Journal of Community Archaeology \& Heritage 4(2): 115-130. DOI: 10.1080/20518196.2016.1252129

Sentencing Council (2015), Theft Offences Definitive Guideline. https://www.sentencingcouncil.org.uk/wp-content/uploads/SC-TheftOffences-Definitive-Guideline-content_FINAL-web_.pdf [Accessed 30 July 2018]

Shadbolt, N., et al. (2012), Linked open government data. [pdf] IEEE Intelligent Systems. Available from: http://ieeexplore.ieee.org/stamp/stamp.jsp?arnumber=6171150 [Accessed 30 
Fool's Gold? A critical assessment of sources of data on heritage crime

May 2018].

Shelbourn, C. (2014), Improving the treatment of heritage crime in criminal proceedings: towards a better understanding of the impact of heritage offences. In Heritage Crime (pp. 188-205), Palgrave Macmillan, London.

Skogan, W. G. (1977), Dimensions of the dark figure of unreported crime. Crime \& Delinquency, 23(1), 41-50.

Sullivan, B.L., Aycrigg, J.L., Barry, J.H., Bonney, R.E., Bruns, N., Cooper, C.B., Damoulas, T., Dhondt, A.A., Dietterich, T., Farnsworth, A. and Fink, D., (2014), The eBird enterprise: an integrated approach to development and application of citizen science. Biological Conservation, 169, pp.31-40.

Sutton, M., Johnston, K., \& Lockwood, H. (1998), Handling stolen goods and theft: A market reduction approach (Vol. 178), London: Home Office.

Thomas, S. (2016), The Future of Studying Hobbyist Metal Detecting in Europe: A Call for a Transnational Approach. Open Archaeology 2(1), 140-149.

Thomas, S. (2014), Vulnerable by design: Theft and Finnish architecture. The Historic Environment: Policy \& Practice, 5(3), 231-244.

Thomas, S. (2013), Portable antiquities: archaeology, collecting, metal detecting. Internet Archaeology 33, doi: https://doi.org/10.11141/ia.33.12

Thomas, S. and Grove, L. (2014), Introduction in Grove, L., \& Thomas, S. (eds.), Heritage crime: progress, prospects and prevention. Palgrave Macmillan. 110 .

Vollgraaff, H. (2014), Developing policy on heritage crime in southern Africa. In Heritage Crime (pp. 169-187), Palgrave Macmillan, London. 
Fool's Gold? A critical assessment of sources of data on heritage crime

\section{Introduction}

Heritage crime is a relatively recent way of looking at crimes that affect the historic environment and broader cultural heritage. It is an interdisciplinary approach to an ancient problem - that of deliberate damage to and destruction of the historic environment. Definitions are continually being debated and discussed with key questions around who defines the ownership of heritage (Hodder 2 2010), the role of the State in its protection or destruction (Hutchings and La Salle 2017), what damage is in itself worthy of protection (cf. Forster, Vettese Forster andBorland et al., 2012 on assessing the cultural worth of ancient and contemporary graffiti) being just some areas of debate. Within this paper, the term heritage crime is used in a pragmatic sense: 'any activity that is prohibited by law that causes loss of, damage to, or other harm to places, monuments or objects considered to be heritage' (Thomas and Grove, $-(2014: 5)$. This is not to dismiss the importance of those other debates, but is a recognition that law enforcement and heritage bodies cannot reasonably be expected to work regularly outside such frameworks.

There are many examples of heritage crime from around the world, including: the destruction of assets at sites such as Nimrud in Iraq through terrorist activity (Danti, 2015); damaging graffiti at Clifford's Tower in England (Shelbourn, 2014); arson at Fantoft Stave Church in Norway (Jerome, 2008); architectural theft and illegal export of Finnish design (Thomas, 2014); looting from the Dodington shipwreck off the coast of South Africa (Vollgraaff, 2014); art stolen from the Isabella Stewart Gardner Museum, for which there is still a reward of \$10 million (Gardner Museum, 2018), as well as the widespread erasure of indigenous traditions, language, and cultures as a result of deforestation (Mitten, 2007). This is before even considering the extensive literature on the global trafficking of cultural objects (e.g. Brodie et al., 2006). It is inevitable that many of these heritage assets are in rural or remote areas, which exacerbates the difficulties associated with identification of criminal activity.

Whilst many of these issues have come to public attention over the years, there are many more that remain undiscovered, or known only to a small number of individuals. Researchers have often turned their gaze to the higher value or higher profile examples of heritage crime, particularly that related to trade in 
antiquities, overlooking the greater volume of low-value cultural objects also in circulation on the market (Thomas, 2016: 144-145). It is difficult to know the true nature and extent of heritage crime, especially rural heritage crime, as a result. This is important because without a baseline understanding of heritage crime, it is not possible to measure whether the problem is increasing or decreasing, nor can hotspots of illicit activity within which to direct crime prevention resources be identified. Market reduction approaches (e.g. Mackenzie ${ }_{2} 2011$ ) cannot be developed without an appreciation of the nature of the market, nor can Roach and Pease's (2016) concept of self-selection policing (that people who commit big crimes also commit little crimes - and the former can be identified by understanding more about the latter) be relied upon if there is no record of lower profile crimes taking place.

The purpose of this paper, therefore, is to explore critically the various sources of data available on heritage crime, and consider how these may be utilised and improved, as well as what alternatives may be available in the future. The area context is predominantly that of England and Wales, however the issues raised are equally applicable on an international stage.

\section{Finding the data: the dark figure of unreported crime}

The dark figure of crime refers to the large amount of crime that 'evades the attention of monitoring systems devised to measure its volume and distribution' (Skogan, 1977: 41). It applies here to heritage crime because much of heritage crime is unrecognised and unreported. This is a particular issue because whilst the remainder of the paper discusses issues around data collection and access, many of the mechanisms deliberated are reliant on the public recognising an incident as a crime and reporting it as such. This then needs to be recorded appropriately by the police.

When considering data about crime, the first source utilised is often the recorded crime available on police systems. In England and Wales there are three common ways of accessing police data. The first of these is open source crime data which is made freely available on the specialist website police.uk. This provides access to a sterilised dataset - covering aggregated crime type, approximate 
location, and outcome - with the aim of improving accountability of the police service (Shadbolt et al.,2012: 16). Privacy legislation, such as the Data Protection Act 1998, in part limits this data, making it deliberately obfuscated for public consumption which severely limits its utility (Quinn et al.,, Cooke and Monaghan, 2017). Of particular interest here, is that not only is there is no category for heritage crime - about which more later - but nor is there a way in which to overlay heritage assets with the available crime data as addresses are obscured. In all, there is little utility of this dataset for (heritage crime) researchers and it does not allow for 'sophisticated research outside of police intelligence hubs' (Quinn et al.,, Cooke and Monaghan-2017: 13).

In England and Wales, there are two alternative ways of accessing relevant police data for heritage crime researchers: Freedom of Information Act (2000) requests, and negotiating direct access to force data through individual forces. These have both shared and independent problems. The Freedom of Information Act 2000 allows for more nuanced data to be requested than is available on police.uk, and each request is considered by forces on an individual basis. Requests should be responded to within 20 working days, and can provide access to more specific pieces of information such as crime type and time of day. However, there are limitations to the Act, and each request may be interpreted differently by individual forces (see Daubney and Grove, forthcoming, for an example of the limited information made available in response to an FOI request on the heritage crime of illicit metal detecting). In addition, the searches required to identify relevant data can be time consuming for the forces involved, and for that reason there is a cost and time limitation on FOI requests (Kingston et al.,, Elliott andThomas-2018). This is applied inconsistently across Forces, and is often mirrored by differences in the way that data is accessed and recorded. There are problems that are common between FOI requests and direct access to police data, as they effectively draw on the same resource in two different ways.

There is usually no 'flag' on the police system to indicate heritage crime (with one known exception, see below). Many other crimes, such as hatemotivated crimes, can be flagged as such by police officers using a checkbox when

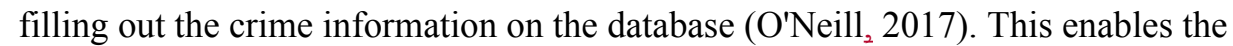
data to be easily retrieved, monitored, and compared across forces. Without this facility, searches for crime types that do not fall into one of the Home Office's 
specific offence classifications (see https://www.gov.uk/government/publications/counting-rules-for-recorded-crime for an up to date list of crimes recorded on the police database) are largely reliant on free-text searches and/or a manual examination of details of crime incidents. Free text fields are often poorly and inconsistently utilised, which means that the level of detail may vary, spelling errors and abbreviations are common, and not all sections are filled out - in short, it becomes difficult to use (Chau et al., Xu and Chen ${ }_{2}$ 2002). Even where researchers or analysts can identify offences, there are well-known issues reconciling addresses on police databases with real-world locations (see for example Ratcliffe and MuCullagh, 1998). This is particularly salient for heritage assets as they may be known by a different name as a heritage asset than as a street address (for example The Old Post Office may also be known as 3 High Street, or may have been separated into multiple residences).

Leicestershire Police are one force that have been proactive in improvements to heritage recording in the crime database, and have provided a tick box to highlight heritage-relevant offences. They are not currently able to assess to what extent officers are using this - and it may be that officers are attending offences and not realising that they are at a heritage asset. One solution under development by Historic England and researchers at Canterbury Christ Church University is a 'proximity app' to inform officers of the protected heritage status of sites they attend.

In addition to problems of recording, there are the difficulties in gaining direct access to police data: this is not possible for all researchers, particularly those without a recognised institutional affiliation, and often relies on direct personal connections which are difficult to duplicate across multiple police force areas. There are also often limits on what may be used due to ethical and privacy considerations, particularly when making use of open source data and FOI requests. A second limitation is the aforementioned flaws in the underpinning data, with existing data not immediately useful for heritage crime researchers.

\section{Under-reporting of heritage crimes}

Some developments which may improve the situation for knowledge and understanding are in progress. Most police forces in England and Wales are now making use of heritage crime officers, who take the lead on local heritage crime 
issues. This arguably improves awareness both within and outside of the force. However, these officers take on the duties on top of other roles, and have little resource to back up their work. As a result, the focus is inevitably on a relatively narrow range of issues, most notably lead theft from church roofs which is a particularly high-profile crime at present. This means that many forms of heritage crime are still relatively under-recorded on the system, even where crimes are identified and reported.

The problem of under-reporting and recording is well recognised in other crime areas. Researchers often attempt to circumvent this by using crime survey data to supplement or as an alternative to police recorded statistics. This goes some way toward addressing the aforementioned dark figure of crime because surveys approach individuals (or businesses) directly in order to ascertain their experiences of victimisation. The main victim survey in England is the Crime Survey for England and Wales (CSEW), which is run by the Office for National Statistics (ONS). Unlike police recorded data in England, the CSEW has the status of 'National Statistics' $\left(\mathrm{ONS}_{2} 2017\right)$ which reflects the high quality and reliability of the dataset. The CSEW (formally known as the British Crime Survey) has been running since 1981 (Kantar 20150NS, 2017) and is one of the largest social research surveys conducted in England and Wales (Home Office, 2012). Internationally, similar surveys exist such as the National Crime Victimization Survey in the USA, and the International Crime Victims Survey which is a multilingual Europe-wide effort. These are invaluable sources of data for crime researchers, but they do not include any questions about heritage. It is feasible that in sections on property crime there could, in the future, be an additional question regarding heritage status. However, this may make it easier to identify individual addresses; at present the data cannot be disaggregated to this extent. Additionally, the survey is expensive and time-consuming to run, and new questions are infrequently added to the survey (recent examples being related to online crime). It therefore seems unlikely that a question on heritage will be added in the foreseeable future, particularly as this would relate to a relatively small subset of the sample.

This lack of focus on heritage-specific topics in existing crime surveys leads to considering heritage-crime as a survey topic in its own right. There have been two large-scale national research surveys published in this that would fit this 
category. In 2009, Oxford Archaeology published the 'Nighthawking Survey'. The report itself, while bringing the issue of nighthawking (more usefully known as illicit metal detecting) back into public discourse at a time when this had abated slightly, can also be criticised, for example due to the relatively low numbers of metal detectorists consulted in the data collection phase (Thomas 2013 ). In 2011/12 two of the present authors collaborated on the Heritage Crime Survey with scholars from Newcastle University (Coombes et al...2012) funded by what was then English Heritage (now renamed Historic England). The project brief was to explore the concept of heritage crime, as defined then by English Heritage as 'any offence which harms the value of England's heritage assets and their settings to this and future generations' (Coombes et al.,2012: 7). The study assessed the extent to which heritage crime could be detected from the available data at that time collected via surveys, police reports, records kept by special interest groups and other sources. The key finding from that survey was that there were an estimated 75,000 crimes affecting designated historic buildings and sites in 2011 (English Heritage, 2012) - a substantial number. This survey has not been duplicated since, and there is no way of telling whether 2011 was a representative year, nor what trends have been seen in heritage crime, or indeed in the way in which such crimes are recorded, since the survey.

In other countries and regions, there have also been attempts to collect data on heritage crimes. One notable example is the report Cultural Heritage Crime: The Nordic Dimension (Korsell et al.2, 2006), which drew together available data for Denmark, Finland, Norway and Sweden. Other internationally-focused sources of data on heritage crimes include the International Council of Museums' Red Lists series (http://icom.museum/programmes/fighting-illicit-traffic/red-list/), as well as lists of known stolen cultural object kept by such as Interpol. These efforts generally focus on one particular kind of heritage crime - looting and trafficking of cultural objects - as their focus tends not to be on the broader spectrum of offenses that may be considered to be heritage crime.

A specific problem with surveying crimes and incidents at heritage assets is that they often have no on-site owner, tenant, or manager. It can be difficult to identify the correct person to talk to about incidents - and even where a person may be identified, it does not necessarily follow that they are monitoring the asset closely. For example, signs of illicit metal detecting on a scheduled monument 
may be disturbed ground and/or tyre tracks, which could be dismissed or ignored without specific cause to check. Other times the natural action of wildlife such as rabbits or moles may be misinterpreted as signs of illicit digging. Many rural assets are isolated which leaves them not only at risk of crime going unnoticed, but also of longer term damage.

Historic England tackles the issue of the deterioration of heritage assets with the annual publication of the Heritage at Risk (HAR) register. The HAR register focuses on deterioration of and damage to assets that are included in the National Heritage List for England (NHLE), such as Grade 2, 2*, and Grade 1 listed buildings, scheduled monuments, registered battlefields, registered parks and gardens, protected wreck sites, and conservation areas. While the NHLE includes around 400,000 assets, this represents just a small portion of the total number of historic sites and monuments across England and Wales which are afforded little or no protection. Assets included in the HAR register are rated according to a number of categories, such as vulnerability, condition, ownership, and priority. 'If a site has suffered from heritage crime it is noted in the summary' (Historic England ${ }_{2}^{2017}$ ) but this is not highlighted as a category in its own right, and nor is the data easily searchable. Unlike the National Heritage List for England, which identifies all protected heritage assets in England and provides data for download and manipulation, the HAR register is published regionally in pdf format. Although a search function exists via the Historic England website, this is not sufficiently granular to permit a search by victimisation. However, the HAR register provides a potential future route for data collection on heritage crime at the most vulnerable sites.

Data on heritage crime principally concerning illicit metal detecting and/or potential breaches of the Treasure Act (1996) in England and Wales are collated in an informal way by the Portable Antiquities Scheme (PAS). The PAS was established in 1997 as mechanism through which archaeological artefacts discovered by the public in England and Wales could be recorded. The scheme is formed by a network of Finds Liaison Officers (FLOs) spread out the regions, who liaise directly with finders (mainly hobbyist metal detectorists). All finds recorded by the scheme are published onto their searchable online database ${ }^{1}$, though spatial

\footnotetext{
${ }^{1}$ www.finds.org.uk/database
} 
and personal data are restricted to bona-fide researchers. While the scheme was established primarily as a way to encourage the recording of finds that do not fall under the Treasure Act (1996), the close liaison that FLOs have with the public has meant that they are often the recipients of information on illicit metal detecting and/or the illicit sale of antiquities. As a consequence, FLOs frequently liaise with law enforcement authorities. Information on the extent of this liaison has only been recorded systematically since 2015 and only in a broad way: the focus of these surveys are not to capture fine detail on specific incidents, but rather to establish broader trends in the reporting of illicit metal detecting, and also the amount of resource that is expended by the scheme in working with law enforcement authorities each year (Daubney, 2017; Daubney and Grove, forthcoming). Accordingly, PAS survey data includes both those incidents that were reported to the Police and which were acted upon, and also those incidents that were reported to Police and which resulted in no further action. Unfortunately the level of detail captured by the PAS surveys do not allow it to be used to differentiate between the two.

At present, the Crown Prosecution Service, which is responsible for criminal prosecutions in England and Wales, records convictions under relevant heritage legislation - for example the Treasure Act 1996 and the Dealing in Cultural Objects (Offences) Act 2003. In practice these laws are rarely used to prosecute an offender, as they are often prosecuted under more common laws such as the Theft Act 1968. This means that there are very few offences identifiable as heritage crime, even though there may in practice be many more relevant prosecutions. As one example, the first prosecution under the Dealing in Cultural Objects (Offences) Act 2003 since its enactment did not come until 2016 (Herman 2016).

Changes to Sentencing Council guidelines, which give guidance on the appropriate prison (or other) sentences for all offences in England and Wales, mean that heritage is an aggravating factor for certain offences (see for example Sentencing Council 2015). This means that where, for example, damage is done under theft offences, but to a recognised heritage asset, judges and magistrates have the ability to hand down a more severe sentence. This may mean that records of heritage-related offences become easier to access in the future, although again this may depend on the ways in which the records are kept; free-text fields are 
invariably harder to search than separate categories or flags for offences.

Data may also be available from a variety of commercial organisations. Some examples of this are insurance companies, auction houses, and businesses that sell crime prevention products. This data is not always accessible to researchers as in many cases commercial companies are under no obligation to share their data with others.

The Art Loss Register is 'the world's largest private database of lost and stolen art, antiques and collectables' (Art Loss Register, 2018). By registering details of such items, the database taps into the principles of the Market Reduction Approach (Sutton ${ }_{2}$ 1998) - namely that by making potential buyers aware of the stolen nature of items, demand is reduced. The potential for recovery is also improved. However, as a commercial company the Art Loss Register charges a fee per search, which minimises its utility for items with a lower monetary value. Indeed, the Art Loss Register only really concerns 'art' that has been stolen from an existing collection; for obvious reasons it does not include items that have been stolen 'straight out of the ground'.

Auction houses also retain records of items that have been sold via their services. This helps build a picture of provenance of cultural and heritage artefacts. This is generally considered to be commercially sensitive information, and auction houses would not wish to risk being associated with potentially criminal activity, and therefore are unlikely to share data with researchers. While it can be possible to analyse data such as provenance descriptions, pre-sale estimates and final sales results (Brodie 2 2014), auction houses generally protect the identity of vendors through client confidentiality. Furthermore, some auction houses occasionally host private, invitation-only sales, for which there are often no publicly available records.

Access might be negotiated to other commercial providers, particularly where a mutual benefit can be demonstrated. There are specialist insurers who maintain datasets for certain items - in the UK for example, Ecclesiastical Insurance provides cover for many listed churches, and so will have data on claims made for thefts. Buildings with a 'listed' (protected heritage) status usually require specific insurance to cover additional costs associated with repair of these assets, 
and there will almost certainly be claims data scattered across a number of such insurers. Insurance data may be skewed toward higher value claims, due to the excess payable on a claim and the risk of increased premiums in future years making lower-value claims ineffective for the victim and if risks 'are likely to remain high after all reasonable precautions have been taken, the insurance company will not underwrite the risk' (Pease ${ }_{2} 1979$ : 32) so data does not account for uninsured properties, which may be proportionately more likely to be damaged. Insurance data can still provide an important (albeit limited) insight to the nature and extent of damage to many occupied heritage assets. The challenge is to access this commercially sensitive data in a usable format. This is a problem also for data from developers of commercial crime prevention products, who may be keen to share data only when it supports their claims to effectiveness.

\section{Collecting Heritage Crime Data}

There are pockets of data collection happening within voluntary groups, albeit sometimes with limited accuracy, that aim to reduce risk of heritage crime in their local area. In England there are a number of such groups: Heritage Watch; Church Watch; Rural Watch, as well as volunteers within the police service. Significant contributions are also made by individuals or groups who attempt to 'self-police' their hobby; this is particularly seen among metal detectorists who frequently report individuals who operate outside of the law. These tend to be decentralised groups that encourage reporting to the police, but may also retain limited records, or more likely an informal institutional knowledge which would be very useful if it were able to be collated, but currently remains in the grasp of a relatively small number of individuals. Oftentimes, individuals who make efforts to gather such data are more than willing to share (cf. the data on illicit metal detecting gathered by Mark Harrison of Historic England and presented in Daubney and Grove ${ }_{2}$ forthcoming) - the problem lies with identifying and contacting the relevant individuals and groups, as well as being able to assess the validity of any data gathered in such a fashion. The types of crimes which come to the attention of individuals and groups are invariably going to be skewed due to the interests of those involved, as well as the awareness of potential informants of the relevant contact details. 
Related to this, it has been argued that many heritage projects and programmes aimed at increasing public engagement are rooted in an aim to reduce crimes such as looting and vandalism through raising awareness (Ellick, 2016). What is less well known, and likely not recorded in most cases (or even possible to record), is the extent to which heritage crimes do reduce as a result of greater community involvement.

The HAR register relies to an extent on risk assessments on specific sites. This is a tactic that can be used on a far more widespread scale by individuals, organisations, and projects. This can be helpful when trying to decide where to prioritise resources. However, if they were also to be shared on a heritage crime database, available to registered professionals and researchers, this would provide an invaluable resource as a knowledge base on the nature and extent of heritage crime. Some police forces, for example Leicestershire Police, have developed risk assessments to be shared with managers of select heritage assets, although these are yet to be rolled out widely and are of limited use until this happens. Due to budgetary and staff limitations, much work on risk assessment relies on 'buy-in' from owners, managers, and tenants of heritage assets. Where the primary use of an asset is not as heritage - for example a church is used predominantly for worship rather than as a heritage asset - it may be more difficult to encourage individuals to participate. There is also little formal evaluation of the effectiveness and helpfulness of these risk assessments. It is useful to develop risk assessments for different contexts to facilitate thinking about important issues that impact on assets, and where appropriate preventive measures may be taken. Two of the authors of the present piece have previously collaborated on such work (see Grove, Baubney and Booth - et al., 2018) and explored various aspects of archaeological sites which may be linked with greater risk: using the acronym HOPPER to draw together aspects of History, Openness, Protected status, Publicity, Evasion, and Repeat Victimisation.

It may also be worth considering the role of the media. As heritage crime becomes more known and of greater interest to readers and viewers, the coverage may in turn become more comprehensive - which may be tracked via online tools such as Google Alerts. Whilst coverage itself will inevitably be skewed to more newsworthy cases - that it, those crimes that occur on a larger scale or with a 
greater negative impact on the community - the more reporting individuals see in the papers, the more likely they are to come forward via formal reporting mechanisms with information and incidents, which in turn improves our knowledge and understanding. Specific campaigns may also help with this process, as has recently been seen with the social and mainstream media coverage of the \#MeToo movement in relation to a $24 \%$ rise in police recorded sexual offences in the year ending March 2018 (ONS, 2018).

When considering the nature and extent of heritage crime, much can be learned from individuals who directly deal with the effects of heritage crime. To date there is remarkably little work using interview data (at the time of writing the authors are only aware of Poyser and Poyser, 2017) Where used, interview data can provide a wealth of useful information related not just to the nature and extent of heritage crime, but also where there may be conflicts between user groups and officials. Poyser and Poyser (2017) approached this question with an exploration of the differing views of heritage crime between police practitioners and heritage professionals. These differing attitudes led to frustrations between the two groups.

Innovative thinking is required when it comes to improving our knowledge base on heritage crime. The realm of so-called 'big data' provides many opportunities to identify heritage assets that have been targeted by offenders (Constantinidis, 2016). Online auction sites and their equivalent on the dark web can be examined for stolen items being resold (Paul, 2018). Photography repositories can be scraped for evidence of damage to heritage assets. (Grove andLockley in preparation).

Crowdsourcing and citizen scientists are used to great effect in other scientific research, and has been especially popular within the galleries, libraries, archives and museums (known shorthand as GLAM) community (Ridge 2 2014). It has also been put to good use in the monitoring of wildlife such as birds (Sullivan et al.22014), and by media agencies for collecting public knowledge of historical periods such as the First and Second World Wars and the Finnish Civil War (Seitsonen 2 2017), to name a few examples.

The heritage community benefits from a large number of volunteers and members of various organisations - for example the National Trust had 2.31 million members in 2016-17 (National Trust, 2017: 5), while English Heritage had 
918000 members in 2016-17 (English Heritage 2 2017). This enthusiasm is not unique to England or the UK. Similar member organisations exist around the world with comparable enthusiasm from members, such as the National Trusts in Australia and Canada. Tapping into this network could provide an excellent source of data - imagine a phone app for easy reporting of damage and uploading of images, automatically geotagged for identification of location - and such a project could be international in scope. Historic England's 'Enrich the List' may provide a template for such a project. ${ }^{2}$ 'Enrich the List' is a dedicated online service where members of the public can share their knowledge and pictures of sites and monuments listed on the NHLE. Most of the information submitted by the public includes photos of sites, stories, or anecdotes, which collectively enhance understanding of the past and present condition of a particular listing. All 'extra' information submitted by the public is moderated by staff from Historic England and then published online after the official entry for that place. Logically, the underlying crowd-sourcing philosophy behind 'Enrich the List' could be applied to heritage crime.

Alas, at present such a project that focusses on heritage assets (listed or otherwise) in England and Wales does not exist, and so researchers remain in limbo - knowing there is a heritage crime problem, but unable to map the extent. There are further challenges concerning data coverage in all areas of the world, particularly relatively remote places with vulnerable heritage assets within the landscape.

Preserving detailed digital records of heritage assets can be seen as controversial, but on the other hand provides a baseline record to compare against, should a heritage crime take place. Additionally, while some have argued against the prevalence of digital heritage due to the loss of authenticity and materiality (e.g. Rekrut, 2014), it has also been seen elsewhere that digitizing cultural heritage, for example using 3D imaging, can not only provide a record of a site's state of preservation at a particular time, but can also open up access to remote locations for communities that have a connection to the site but lack the means to access it regularly (e.g. Haukaas and Hodgetts ${ }_{2}$ 2016). However, without large scale policies - possibly making use of crowdsourcing and other voluntary collaborative methods

\footnotetext{
${ }^{2}$ https://www.historicengland.org.uk/listing/enrich-the-list/
} 

projects.

\section{A call to action}

Rather than conclude with a summing up of the points and observations made in this paper, the discussion will be closed with a call to action with regard to the future of heritage crime data. Good quality data is important for a number of reasons:

An understanding of the patterns in heritage crime is essential to know where it clusters, and therefore where to target limited crime prevention resources

Changes over time need analysis so that micro and macro trends can be identified - and predictions made on future trends. This is also useful to see whether interventions being made are having an effect

Knowing the extent of heritage crime allows an argument for a commensurate apportioning of resource to tackling the problems

It allows for an understanding of the shape of victimisation are some groups disproportionately affected over others? This is apparent for example in the field of green criminology: namely environmental racism whereby policies disproportionately affect ethnic minorities (cf. Cole and Foster, 2001). Good data allows identification of whether heritage is disproportionately deteriorating in areas of poverty, for example. Support can then be offered to the worst affected in society.

It is useful to know if there are links with other types of crime the aforementioned concept of self-selection policing. Again, the greater an understanding we have of these issues, the more able to target resources accordingly - if focusing on heritage offences can help to prosecute people who are also responsible for e.g. terrorist activity, this is a good use of resources.

This leads the argument naturally to a further point to consider. When there is greater reporting of a crime to the relevant authorities, this does not necessarily mean there are more incidents. Rather than greater numbers of incidents, greater 
reporting may mean more awareness of legalities, a greater identification of relevant incidents, and better knowledge of how to report. It may mean a greater confidence in reporting - as police are seen to take incidents more seriously there may be a boost to people being willing to report future events. The publicity surrounding successful prosecutions, can also increase people's belief that something can be done which again is linked to an increased level of reporting (cf. $\mathrm{ONS}_{2}$ 2018). For example the 2018 prosecution of divers looting a World War I Navy shipwreck received coverage from across UK media (cf. BBC, 2018; $;$ Boyd $_{2}$ 2018). A larger number of reports may also mean that recording practices have improved. Finally, as laws and Home Office counting rules change, incidents may be recorded as a crime by police where previously they were 'no-crimed', thus making figures look artificially higher in comparison with previous years.

The following steps are therefore suggested, initially in the English context but with the intention of rolling out successful elements to other countries and contexts once initial difficulties are ameliorated. Of course, all of the suggested methods focus predominantly on tangible heritage, and could be seen to neglect the intangible nature of much heritage - stories, culture, song, language for example. This reflects the more difficult nature of measuring such issues - and is in no way intended as a commentary on the relative importance of tangible and intangible heritage.

- A regular victimisation survey is undertaken, to get a snapshot of changes and progress

- Heritage crime is flagged as part of routine data collection in the police

- These two items combined provide police recorded data, and crime statistics that are not affected by changes in recording practices, for comparison purposes.

- An analyst should be appointed in the first instance to assess the national picture and to provide predictions of where future problem areas may lie. In the longer term, it would be useful to see a team akin to the National Wildlife Crime Unit be developed alongside an academic partnership to facilitate proactive working and the introduction of predictive and protective measures. 


\section{References}

Art Loss Register (2018), “About Us”, available at:- http://www.artloss.com/aboutus/our-company ㅌ. aAccessed 13 June 2018). 7

BBC (2018), "Pair plundered HMS Hermes shipwreck in Dover Strait 22 June 2018", available at:- https://www.bbc.com/news/uk-england-kent-44536788 (faaAccessed 30 July 2018).]

Boyd, C. (2018), “Diver and boat owner who stripped thousands of pounds of metal from shipwrecks including WWI cruiser HMS Hermes in the English Channel are jailed for up to four years each", -23 June-2018, available at:http://www.dailymail.co.uk/news/article-5875537/Divers-strippedthousands-pounds-metal-shipwrecks-jailed-four-years-each.html (a[Accessed 30 July 2018=.]

Brodie, N. (2014), "Provenance and price: autoregulation of the antiquities market?", European Journal on Criminal Policy and Research, Vol. 2020 No. (4), pp. $427-444$. 
Brodie, N., Kersel, M. M., Luke, C., and \& Walker Tubb, K. (Eds.) (2006), Archaeology, cultural heritage, and the antiquities trade ${ }_{2}=$ University Press of Florida, Gainesville. :

Chau, M., Xu, J. J., \& Chen, H. (2002, May), “Extracting meaningful entities from police narrative reports", inIn Proceedings of the 2002 annual national conference on Digital government research, Los Angeles (pp. 1-5), Digital Government Society of North America, pp. 1-5.-

Cole, L.W. and Foster, S.R., (2001), From the ground up: Environmental racism and the rise of the environmental justice movement ${ }_{2}-$ NYU Press, New York.

Constantinidis D. (2016), "Crowdsourcing Culture: Challenges to Change”, Borowiecki, K., Forbes, N., and Fresa, A. (Eeds.), Cultural Heritage in a Changing World. Springer, Cham, pp_.215-234.

Coombes, M., Bradley, D., Grove, L., Thomas, S. and $\&$ Young, C. (2012), The extent of crime and anti-social behaviour facing designated heritage assets. English Heritage, London.

Danti, M. D. (2015), “Ground-based observations of cultural heritage incidents in Syria and Iraq",-Near Eastern Archaeology, Vol. 78 No. (-3), pp. 132-141.

Daubney, A. (2017), "Floating culture: the unrecorded antiquities of England and Wales"., Internatiiional Journal of Heritage Studies, Vol. 23 No. (9), pp. 785-799.

Daubney, A. and Grove, L. (forthcoming), Detecting heritage crime(s): what we know about illicit metal detecting in England and Wales, Journal of Cultural Property

Ellick, C. J. (2016), “A Cultural History of Archaeological Education”.- Advances in Archaeological Practice, Vol. 4 No. (4), pp. 425-444. 


\section{Forster, A. M., Vettese-Forster, S., and $\&$ Borland, J. (2012), "Evaluating the} cultural significance of historic graffiti”,- Structural Survey, Vol. 30 No. $(1)$, pp. 43-64.

Gardner Museum (2018), “Gardner Museum Theft: An Active And Ongoing Investigation", available athttps://www.gardnermuseum.org/organization/theft (Faccessed 13 June 2018). 7

Grove, L., Daubney, A., and $\&$ Booth, A. (2018), "Identifying sites at risk from illicit metal detecting: from CRAVED to HOPPER,,- International Journal of Heritage Studies, Vol. 24, No. 10, pp1-15.1038-1052.

Haukaas, C., and L. M. Hodgetts (2016), “The untapped potential of low-cost photogrammetry in community-based archaeology: a case study from Banks Island, Arctic Canada",- Journal of Community Archaeology \& and Heritage Vol. 3 No.(1.), pp. 40-56. DOI: doi.org/10.1080/20518196.2015.1123884

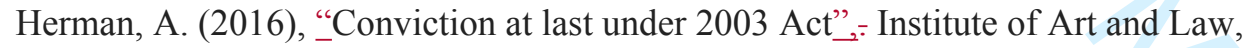
11 May, available at: https://ial.uk.com/1448-2/ (a[Accessed 5 July 2018)].

Hodder, I. (2010), "Cultural heritage rights: From ownership and descent to justice and well-being”, Anthropological Quarterly, Vol. 83 No. (4),pp. 861-882.

Home Office (2012), "British Crime Survey: methodology",- London:-Home Office, London, available athttps://www.gov.uk/government/statistics/british-crime-survey-methodology (ac[Accessed 13 June 2018).]

Hutchings, R. M., and\& La Salle, M. (2017), “Archaeology as State Heritage 
Fool's Gold? A critical assessment of sources of data on heritage crime

Korsell, L., G. Hedlund, S. Elwér, D. Vesterhav, and\& A. Heber. (2006), Cultural Heritage Crime: The Nordic Dimension, ; Stockholm:-The Swedish National Council for Crime Prevention, Stockholm.-

Mackenzie, S. (2011), "The Market as Criminal and Criminals in the Market: Reducing Opportunities for Organised Crime in the International Antiquities Market", in Manacorda, S., and Chappell, D. (Eeds.), Crime in the Art and Antiquities World. Springer, New York, pp. -69-85.

Mitten, L. (2007), “The human cost of deforestation",- Peace Review, Vol. 9 No. (4), pp. 549-553, DOI: 10.1080/10402659708426107

National Trust (2017), “National Trust Annual Report 2016/17”,- Swindon:National Trust, Swindon, available athttps://www.nationaltrust.org.uk/documents/annual-report-201617.pdf (a[Accessed 9 July 2018).]

O'Neill, A. (2017), "Hate Crime, England and Wales, 2016/17”,- Statistical Bulletin 17/17, Home Office, London. . London: Home Office. https://assets.publishing.service.gov.uk/government/uploads/system/uploadst attachment_data/file/652136/hate-crime-1617 hosb1717.pdf

ONS (2017), “Crime in England and Wales: year ending June 2017”, available athttps://www.ons.gov.uk/peoplepopulationandcommunity/crimeandjustice/bu

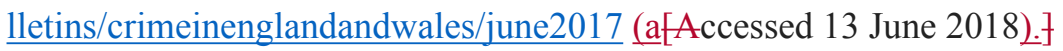

ONS (2018), “Crime in England and Wales: year ending March 2018”, available at:https://www.ons.gov.uk/peoplepopulationandcommunity/crimeandjustice/bu 
$\underline{\text { lletins/crimeinenglandandwales/june2017 [Accessed } 23 \text { July 2018] (accessed }}$ 23 July 2018).

Oxford Archaeology (2009), "Nighthawks and Nighthawking: Damage to Archaeological Sites in the UK and Crown Dependencies caused by Illegal Searching and Removal of Antiquities", available at https://historicengland.org.uk/images-books/publications/nighthawksnighthawking/ (accessed 2 October 2018)

Paul, K. A. (2018), “Ancient Artifacts vs. Digital Artifacts: New Tools for Unmasking the Sale of Illicit Antiquities on the Dark Web", Arts Vol. 7 No. (2), 12, pp.1-19. . DOI: 10.3390/arts7020012

Pease, K., (1979), “Some futures in crime prevention”,- Home Office Research Bulletin, Vol. 7, pp.31-35.

Poyser, B. and Poyser, S., (2017), “Police practitioners and place managers' understandings and perceptions of heritage crime in Nottinghamshire" $\mathrm{e}_{2} \cdot$ International Journal of Police Science and\& Management, Vol. 19 No. (4), pp._247-260.

Quinn, A., Cooke, L., and \&Monaghan, M. (2017), “An exploration of the progress of open crime data: how do ongoing limitations with the Police.uk website restrict a comprehensive understanding of recorded crime?", Policing and Society, (online first), 1-16.

Ratcliffe, J. H., and $\&$ McCullagh, M. J. (1998), “Identifying repeat victimization with GIS", The British Journal of Criminology, 38Vol. (4) No. 1, pp 651662.

Rekrut, A. (2014), "Matters of Substance: Materiality and Meaning in Historical records and their Digital Images", Archives and Manuscripts Vol. 42 No. $(-3$, pp.) $): 238-247$.

Ridge, M. (2014), “Crowdsourcing our Cultural Heritage: Introduction”,. Fin M. 


\section{Roach, J., and $\&$ Pease, K. (2016), Self-Selection Policing: Theory, Research and} Practice. Springer.

Seitsonen, O. (2017), "Crowdsourcing cultural heritage: public participation and conflict legacy in Finland",-. Journal of Community Archaeology and $\&$ Heritage Vol. 4 No. $(2$, pp. $) \div 115-130$. DOI: $10.1080 / 20518196.2016 .1252129$

Sentencing Council (2015), “Theft Offences Definitive Guidelinee.”, available at https://www.sentencingcouncil.org.uk/wp-content/uploads/SC-TheftOffences-Definitive-Guideline-content_FINAL-web_pdf (A[Accessed 30 July 2018). $\}$

Shadbolt, N., O’Hara, K., Berners-Lee, T., Gibbins, N., Glaser, H., Hall, W., and Schraefel, M. C.Shadbolt, N., et al. (2012), "Linked open government data: Lessons from Data.gov.uk" ${ }_{2}$ [pdf] IEEE Intelligent Systems, Vol. 27 No. 3, pp. 16-24. EEE Intelligent Systems. Availablefrom: http://ieeexplore.ieee.org/stamp/stamp.jsp?arnumber $=6171150$ [Accessed 30 May 2018].

Shelbourn, C. (2014), "Improving the treatment of heritage crime in criminal proceedings: towards a better understanding of the impact of heritage offences", in Grove, L., and Thomas, S. (Eds.). In Heritage Crime: Progress, Prospects and Prevention. - (105), Palgrave Macmillan, LondonBasingstoke, .(pp. 188-205.),

Skogan, W. G. (1977), "Dimensions of the dark figure of unreported crime",Crime and \& Delinquency, Vol. 23 No. (1), pp. 41-50.

Sullivan, B.L., Aycrigg, J.L., Barry, J.H., Bonney, R.E., Bruns, N., Cooper, C.B., Damoulas, T., Dhondt, A.A., Dietterich, T., Farnsworth, A. and Fink, D., (2014), “The eBird enterprise: an integrated approach to development and 


\section{Sutton, M., Johnston, K., and \& Lockwood, H. (1998), Handling stolen goods and} theft: A market reduction approach ${ }_{2}+($ Vol. 178),_London:Home Office, London.-

Thomas, S. (2016), “The Future of Studying Hobbyist Metal Detecting in Europe: A Call for a Transnational Approach.', Open Archaeology Vol. 2 No. 2(1), pp. 140-149.

Thomas, S. (2014), "Vulnerable by design: Theft and Finnish architecture",- The Historic Environment: Policy and\& Practice, Vol. 5 No. (-3), pp. 231-244.

Thomas, S. (2013), "Portable antiquities: archaeology, collecting, metal detecting",- Internet Archaeology Vol. 33, doi:https://doi.org/10.11141/ia.33.12

Thomas, S. and Grove, L. (2014), “Introduction”, in Grove, L., and \& Thomas, S. (Eeds.), Heritage Crime: Progress, Prospects and PreventionHeritage erime: progress, prospects and prevention., Palgrave Macmillan, Basingstoke, pp.: 1-10.

Vollgraaff, H. (2014), "Developing policy on heritage crime in southern Africa”,fin Grove, L., and Thomas, S. (Eds.) Heritage Crime: Progress, Prospects and Prevention, Heritage Crime (pp. 169 187), Palgrave Macmillan, LondenBasingstoke, pp. 169-187.- 